\title{
Rekomendasi Pemetaan Keahlian Siswa terhadap Spesifikasi Lowongan Kerja pada Sistem Bursa Kerja Khusus Menggunakan Metode SAW di SMK
}

\author{
Nanda Riski Septania, Hakkun Elmunsyah, Utomo Pujianto \\ Jurusan Teknik Elektro, Fakultas Teknik, Universitas Negeri Malang
}

\section{Edcomtech}

\section{Jurnal Kajian}

Teknologi Pendidikan

Volume 4, No 2, Oktober 2019

120-129

Submitted 25-06-2019

Accepted 29-08-2019

Corresponding Author Nanda Riski Septania nseptania@gmail.com

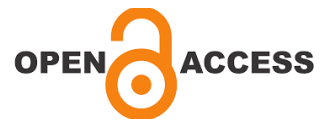

\begin{abstract}
Abstrak
Penelitian ini bertujuan untuk menghasilkan rekomendasi berupa daftar lowongan kerja sesuai dengan keahlian siswa. Model yang digunakan dalam penelitian dan pengembangan rekomendasi pemetaan keahlian siswa adalah waterfall. Teknik pengujian yang digunakan adalah pengujian secara black box, yakni digunakan untuk menguji dari fungsionalitas sistem. Produk divalidasi oleh dua orang ahli, yaitu ahli I dan ahli II. Hasil validasi yang dilakukan oleh ahli I dan ahli II masing-masing memperoleh presentase kelayakan 100\%. Kemudian dari hasil uji coba produk diperoleh presentase kelayakan 97\%. Hasil tersebut menunjukkan bahwa tingkat kelayakan produk sudah valid karena melebihi batas minimal $76 \%$ untuk kriteria valid, sehingga produk dapat dikatakan layak dan dapat digunakan.
\end{abstract}

Kata Kunci: pemetaan keahlian, lowongan kerja, BKK, SAW

\begin{abstract}
This study aims to produce recommendations in the form of a list of job vacancies in accordance with the expertise of students. The model used in research and development of student expertise mapping recommendations is the waterfall. The testing technique used is black box testing, which is used to test the system's functionality. The product was validated by two experts, namely Expert I and Expert II. The results of the validation carried out by expert I and expert II each received a $100 \%$ eligibility percentage. Then from the product trial results obtained a percentage of eligibility $97 \%$. These results indicate that the level of product eligibility is valid because it exceeds the minimum limit of $76 \%$ for valid criteria, so the product can be said to be feasible and can be used.
\end{abstract}

Keywords: mapping expertise, job vacancies, BKK, SAW 


\section{LATAR BELAKANG}

Salah satu pihak penyalur informasi atau mediator dalam dunia usaha dan industri di instansi sekolah menengah tingkat atas khususnya Sekolah Menengah Kejuruan (SMK) adalah Bursa Kerja Khusus (BKK) (Amalina \& Putri, 2017). Selain menjadi pihak penyalur informasi, BKK juga turut berperan dalam meningkatkan mutu dalam sekolah, salah satu jembatan antara wali murid dalam memecahkan masalah ketenagakerjaan, dan membantu lulusan yang belum mendapatkan pekerjaan (Haryani, dkk., 2013). Peran-peran BKK tersebut berdasar kepada Undang- undang No. 14 Tahun 1969 mengenai pokok-pokok ketenagakerjaan dan Perjanjian Kerjasama antar Departemen Pendidikan dan Kebudayaan dan Departemen Tenaga Kerja Republik Indonesia Nomor 076/U/1993 dan Nomor Kep. 216/ Mei/1993 tentang pembentukan bursa kerja dan pemanduan penyelenggara bursa kerja di satuan pendidikan menengah dan pendidikan tinggi, bahwa SMK menjadi salah satu yang bertanggung jawab dalam menyiapkan Sumber Daya Manusia (SDM) yang handal dan berorientasi pada kebutuhan pasar industri.

Kinerja dari BKK adalah salah satu penentu dari keterserapannya lulusan SMK ke dunia industri yang sesuai dengan keahlian masingmasing lulusan (Pambayun \& Wagiran, 2014). Namun faktanya, dalam pengimplementasian BKK kurang maksimal dalam menjalankan peran yang menjadi tanggung jawabnya. Hasil wawancara dengan humas di beberapa sekolah kejuruan di Malang, SMK Negeri 8 Malang dan SMKN 2 Singosari, menyatakan bahwa permasalahan yang sering terjadi pada BKK adalah: (1) belum maksimalnya sistem informasi BKK di sekolah tersebut, (2) lowongan pekerjaan yang ditampilkan masih terbatas, dan (3) pemetaan keahlian siswa masih dilakukan secara manual. Oleh karena itu selain diperlukan giatnya peran BKK dalam mencari informasi mengenai lowongan pekerjaan dan meningkat kualitas layanan BKK (Rahardjo, 2012), maka diperlukan pula sebuah metode yang dapat memetakan keahlian siswa terhadap spesifikasi yang diharapkan oleh lowongan pekerjaan.

Dalam penelitian dan pengembangan sebelumnya tentang sistem informasi BKK menurut Triswandi (2015) untuk mengubah sistem pengelolaan BKK menjadi online sistem, didapatkan hasil uji fungsionalitas sebesar $100 \%$ dan hasil uji usabilitas sebesar $88,70 \%$ yang menunjukkan bahwa sistem informasi ini berfungsi sesuai kebutuhan pegguna. Namun, sistem informasi BKK tersebut belum terdapat solusi yang dapat memecahkan permasalahan yang telah diuraikan diatas. Sehingga diperlukan sebuah metode yang dapat menyelesaikan persoalan tidak terstruktur secara sederhana yaitu metode SAW (Simple Additive Weighting) (Firdausa, dkk., 2016). Metode SAW sebelumnya pernah dikembangkan dalam bidang pendidikan dan kesehatan. Dalam bidang pendidikan, SAW digunakan untuk menentukan pemilihan sekolah (Firdausa, dkk., 2016), rekomendasi prakerin (Santoso, dkk., 2018), peminatan di SMA (Mutaqin, dkk., 2016), penentuan reviewer pada portal PKM (Zakaria, dkk., 2018). Sedangkan dalam bidang kesehatan digunakan untuk memprediksi daerah yang sering terjangkit dengue (Noviarti dkk., 2018), dan pemberian jenis makanan sehat pada batita (Mukodimah dkk., 2018).

Berdasarkan pada permalasahan yang telah diuraikan, maka dilaksanakan penelitian dan pengembangan dengan judul "Rekomendasi Pemetaan Keahlian Siswa Terhadap Spesifikasi Lowongan Kerja pada Sistem Bursa Kerja Khusus Menggunakan Metode SAW di SMK". Tujuan dari penelitian dan pengembangan ini adalah membangun sebuah sistem yang dapat memberikan rekomendasi pemetaan keahlian siswa terhadap spesifikasi lowongan kerja berbasis web serta sistem yang dapat memberikan informasi lebih rinci mengasilkan rekomendasi pemetaan keahlian siswa terhadap lowongan kerja adalah hasil dari penelitian dan pengembangan ini.

\section{METODE PENELITIAN Model Waterfall}

Model penelitian dan pengembangan yang digunakan adalah model waterfall. Model ini dipilih sebab melakukan pengembangan secara berurutan, sistematis dan kebutuhan dari sistem dapat terdefinisi dengan jelas (Romadhoni, dkk., 2015) (Alshamrani \& Bahattab, 2015). Model ini memiliki lima fase tahapan, yaitu: (1) communication, (2) planning, (3) modeling, (4) construction, (5) deployment (Pressman, 2015). 


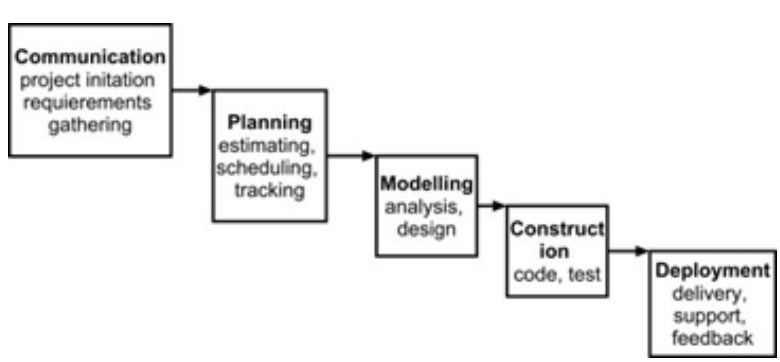

Gambar 1. Model Pengembangan Waterfall

Penggunaan model waterfall memberikan keuntungan perangkat lunak akan selesai tepat waktu dengan prediksi yang sesuai dengan kebutuhan fungsional (Balaji, 2012)often used in software development processes, in which progress is seen as flowing steadily downwards (like a waterfall. Implementasi dari sistem informasi menggunakan xampp yang berguna sebagai web server, MySQL dan PHPmyAdmin sebagai database, dan sublime sebagai editor untuk penulisan script PHP, CSS, bootstrap, HTML.

\section{Simple Additive Weighting}

Metode yang digunakan untuk mendukung keputusan pada sistem informasi ini adalah metode SAW. Metode ini dikenal dengan istilah penjumlahan terbobot. Konsep dasar dari metode SAW adalah mencari penjumlahan terbobot dari rating kinerja pada setiap alternatif dari semua kriteria (Sahir, dkk., 2017)a system is needed that can support the decision making done by the manager. Utilization of decision support system using Simple Additive Weighting (SAW. Metode ini digunakan karena mampu melakukan penilaian secara lebih akurat karena didasarkan pada bobot setiap kriteria dan bobot preferensi yang sudah ditentukan (Mutaqin, dkk., 2016). Berikut adalah langkah-langkah metode SAW (Darmastuti, 2013):

a) Menetukan kriteria (C) yang dijadikan acuan dalam pengabilan keputusan.

b) Rumus nilai rating kecocokan pada masingmasing alternatif dari semua kriteria.

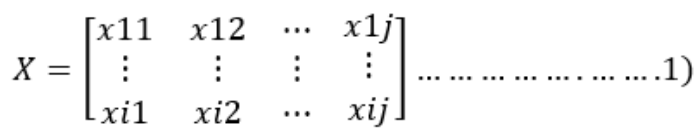

c) Perhitungan normalisasi matriks berdasarkan persamaan yang telah sesuai dengan jenis atribut

$$
r_{i j}=\left\{\begin{array}{r}
\frac{x_{i j}}{\operatorname{Max} x_{i j}} \\
i \\
\operatorname{Min} x_{i j} \\
\frac{i}{x_{i j}}
\end{array}\right.
$$

Hasil dari nilai kinerja ternormalisasi $\left(r_{i j}\right)$

$$
X=\left[\begin{array}{cccc}
r 11 & r 12 & \cdots & r 1 j \\
\vdots & \vdots & \vdots & \vdots \\
r i 1 & r i 2 & \cdots & r i j
\end{array}\right]
$$

d) Hasil dari nilai alternatif untuk solusi terbaik

$$
V_{i}=\sum_{j=1}^{n} W_{j} r_{i j}
$$

\section{Pemodelan Metode}

Proses perhitungan menghasilkan rekomendasi tiap alternatif (A). Alternatif (A) yang dihasilkan berdasarkan pemberian masing-masing bobot kriteria.

a) Menentukan kriteria (C)

Kriteria ditentukan berdasarkan hasil dari wawancara Humas SMKN 8 Malang dan SMKN 2 Singosari, sehingga didapatkan lima kriteria. Lima kriteria yang mempengaruhi pemilihan lowongan pekerjaan adalah nilai siswa (C1), gaji (C2), skill (C3), jurusan (C4), lokasi perusahaan (C5).

b) Menentukan bobot masing-masing kriteria (W)

Bobot kriteria ditentukan dengan menggunaan skala $1 \mathrm{~s} / \mathrm{d} 10$. Kriteria yang menjadi prioritas utama akan diberikan nilai lebih tinggi dari pada kriteria yang dianggap lebih rendah.

Tabel 1. Contoh Pemberian Nilai Bobot

\begin{tabular}{|c|l|c|c|}
\hline No & \multicolumn{1}{|c|}{ Kriteria } & $\begin{array}{c}\text { Nilai } \\
\text { Bobot }\end{array}$ & $\begin{array}{c}\text { Nilai Bobot } \\
\text { Ternormalisasi }\end{array}$ \\
\hline 1 & Nilai siswa (C1) & 8 & 0,2667 \\
\hline 2 & Gaji (C2) & 8 & 0,2667 \\
\hline 3 & Skill (C3) & 5 & 0,1667 \\
\hline 4 & Jurusan (C4) & 4 & 0,1333 \\
\hline 5 & Lokasi (C5) & 5 & 0,1667 \\
\hline
\end{tabular}


c) Memberikan nilai rating kecocokan Tahap selanjutnya adalah memberikan nilai rating pada setiap kriteria sebagai pemenuhan masukan dari pengguna agar diperoleh Alternatif (A).

Tabel 2. Contoh Pemberian Nilai Kecocokan

\begin{tabular}{|l|l|l|c|l|l|}
\hline A & C1 & C2 & C3 & C4 & C5 \\
\hline Perusahaan 1 & 8,5 & 2000000 & 3 & MM & Malang \\
\hline Perusahaan 2 & 8,0 & 5000000 & 4 & TKJ & Malang \\
\hline Perusahaan 3 & 9,0 & 2000000 & 4 & RPL & Malang \\
\hline
\end{tabular}

Berdasarkan pada Tabel 2, tidak semua data dapat dilakukan proses perhitungan seperti data angka, sehingga bagian data yang masih berbentuk variabel dikonversi menjadi angka.

Tabel 3. Konversi Jurusan

\begin{tabular}{|l|l|}
\hline Kategori & Nilai \\
\hline Sesuai & 1 \\
\hline Tidak Sesuai & 0 \\
\hline
\end{tabular}

Tabel 4. Konversi Lokasi

\begin{tabular}{|l|l|}
\hline Kategori & Nilai \\
\hline Malang & 1 \\
\hline Luar Malang & 0 \\
\hline
\end{tabular}

Tabel 5. Contoh Nilai Kecocokan

\begin{tabular}{|l|l|l|l|l|l|}
\hline A & C1 & C2 & C3 & C4 & C5 \\
\hline Perusahaan 1 & 8,5 & 2000000 & 3 & 1 & 1 \\
\hline Perusahaan 2 & 8,0 & 5000000 & 4 & 1 & 1 \\
\hline Perusahaan 3 & 9,0 & 2000000 & 4 & 1 & 1 \\
\hline
\end{tabular}

Setelah semua data telah terkonversi menjadi angka, maka pencarian rekomendasi alternatif dapat dilakukan.

d) Menormalisasi Nilai Kecocokan

Dalam proses menormalisasi nilai kecocokan diperlukan keterangan jenis kriteria pada masing-masing kriteria. Jenis keterangan dari kriteria adalah cost dan benefi (Zakaria, dkk., 2018). C1 dan C2 adalah cost, sedangkan C3, C4 dan C5 adalah benefit. Berikut adalah perhitungan normalisasi nilai kecocokan:
1. $\mathrm{C} 1-$ cost

Nilai minimun pada Tabel 5 bagian kriteria C1 adalah 8,0, maka C1=. Berikut adalah hasil perhitungan normalisasi:

Tabel 6. Hasil Normalisasi

\begin{tabular}{|l|l|}
\hline Nilai & Normalisasi \\
\hline$R_{11}$ & 0,942 \\
\hline$R_{21}$ & 1 \\
\hline$R_{31}$ & 0,889 \\
\hline
\end{tabular}

2. $\mathrm{C} 2-$ cost

Nilai minimum pada Tabel 5 bagian kriteria C2 adalah 2000000, maka didapatkan Berikut adalah hasil perhitungan normalisasi:

Tabel 7. Hasil Normalisasi

\begin{tabular}{|l|l|}
\hline Nilai & Normalisasi \\
\hline$R_{12}$ & 1 \\
\hline$R_{22}$ & 0,4 \\
\hline$R_{32}$ & 1 \\
\hline
\end{tabular}

3. C3-benefit

Nilai maksimal pada Tabel 5 bagian kriteria C3 adalah 3, maka C3=. Berikut adalah hasil perhitungan normalisasi:

Tabel 8. Hasil Normalisasi

\begin{tabular}{|l|l|}
\hline Nilai & Normalisasi \\
\hline$R_{13}$ & 0,75 \\
\hline$R_{23}$ & 1 \\
\hline$R_{33}$ & 1 \\
\hline
\end{tabular}

4. C4-benefit

Nilai maksimal pada Tabel 5 bagian kriteria C4 adalah 1, maka C4 $=$. Berikut adalah hasil perhitungan normalisasi:

Tabel 9. Hasil Normalisasi

\begin{tabular}{|l|l|}
\hline Nilai & Normalisasi \\
\hline$R_{14}$ & 1 \\
\hline$R_{24}$ & 1 \\
\hline$R_{34}$ & 1 \\
\hline
\end{tabular}




\section{C5-benefit}

Nilai maksimal pada Tabel 5 bagian kriteria C5 adalah 1, maka C5 = . Berikut adalah hasil perhitungan normalisasi:

Tabel 10. Hasil Normalisasi

\begin{tabular}{|l|l|}
\hline Nilai & Normalisasi \\
\hline$R_{15}$ & 1 \\
\hline$R_{25}$ & 1 \\
\hline$R_{35}$ & 1 \\
\hline
\end{tabular}

Setelah dilakukan proses normalisasi nilai dari masing-masing kriteria, sehingga telah didapatkan matriks normalisasi setiap alternatif seperti berikut:

Tabel 11. Contoh Nilai Kecocokan yang Ternormalisasi

\begin{tabular}{|l|c|c|c|c|c|}
\hline A & C1 & C2 & C3 & C4 & C5 \\
\hline Perusahaan 1 & 0,942 & 1 & 0,75 & 1 & 1 \\
\hline Perusahaan 2 & 1 & 0,4 & 1 & 1 & 1 \\
\hline Perusahaan 3 & 0,889 & 1 & 1 & 1 & 1 \\
\hline
\end{tabular}

e) Merangking Alternatif

Tahap ini dilakukan proses penjumlahan dari hasil perkalian matriks ternormalisasi dengan nilai bobot. Dari perhitungan tersebut akan diperoleh rangking alternatif. Setiap ranking alternatif akan menghasilkan nilai preferensi. Nilai prferensi yang paling tinggi akan menjadi alternatif rekomendasi yang terbaik dalam menentukan keputusan. $V_{i}=\sum_{j=1}^{n} W_{j} R_{i}$

Tabel 12. Contoh Hasil Rekomendasi Alternatif dan Preferensi

\begin{tabular}{|l|l|l|}
\hline Alternatif & Preferensi (V) & Ranking \\
\hline Perusahaan 1 & 0,9427 & 1 \\
\hline Perusahaan 2 & 0,839 & 3 \\
\hline Perusahaan 3 & 0,9704 & 2 \\
\hline
\end{tabular}

\section{Desain Uji Coba}

Desain uji coba yang diterapkan dalam sistem informasi adalah uji coba pengguna dan uji coba ahli sistem. Uji coba pengguna bertujuan untuk melihat bagaimana respon langsung dari pengguna yaitu siswa SMK terhadap fungsionalitas sistem. Sedangkan, uji coba ahli sistem informasi untuk mengetahui tingkat fungsionalitas pengelola dan pengguna sistem. Pengujian yang dilakukan menggunakan teknik black box.Teknik black box merupakan pengujian yang difokuskan kepada fungsionalitas dari perangkat lunak (Jaya, 2018).

\section{Subjek Uji Coba}

Subjek uji coba yang digunakan untuk menguji sistem informasi ini adalah ahli sistem informasi dan siswa SMK kelas xi. Ahli sistem informasi dilakukan oleh Ahli I dan Ahli II, sedangkan uji coba pengguna dilakukan oleh siswa SMK N 2 Singosari jurusan Mekatronika, RPL, TKJ, Multimedia. Sampel minimal yang didapatkan dari rumus Slovin dan Taro Yamane menggunakan proporsional random sampling adalah 158.

\section{Instrumen Pengumpulan Data}

Instrumenyang digunakandalampengumpulan data adalah kuisioner checklist. Kisi-kisi instrumen berdasarkan pada aspek-aspek fungsionalitas. Perlakuan pada instrumen ini berdasar pada tanda centang pada kolom tersedia dan tidak tersedia. Jika kebutuhan fugsional tersedia dalam sistem informasi, makapilihan tersedia, jika kebutuhan fungsionalitas tidak tersedia, maka tertulis tidak tersedia.

\section{Teknik Analisis Data}

Teknik analisis data yang digunakan pada hasil pengujian sistem ini dalah valid dan tidak valid (Arikunto, 2006). Kriteria tersebut digunakan sebagai pernyataan valid atau tidaknya sistem yang dikembangkan.

$$
P=\frac{\sum x}{\sum x i} \times 100 \%
$$

Keterangan:

$\mathrm{P}=$ Presentase valid

$\mathrm{x}$ = Jumlah jawaban benar responden

$\mathrm{xi}=$ Jumlah jawaban benar soal

Tabel 13. Kriteria Validasi Analisis Presentase

\begin{tabular}{|l|l|}
\hline Presentase & Kriteria Validasi \\
\hline $76-100$ & Valid \\
\hline $56-75$ & Cukup Valid \\
\hline $40-55$ & Kurang Valid \\
\hline $0-39$ & Tidak Valid \\
\hline
\end{tabular}




\section{HASIL DAN PEMBAHASAN}

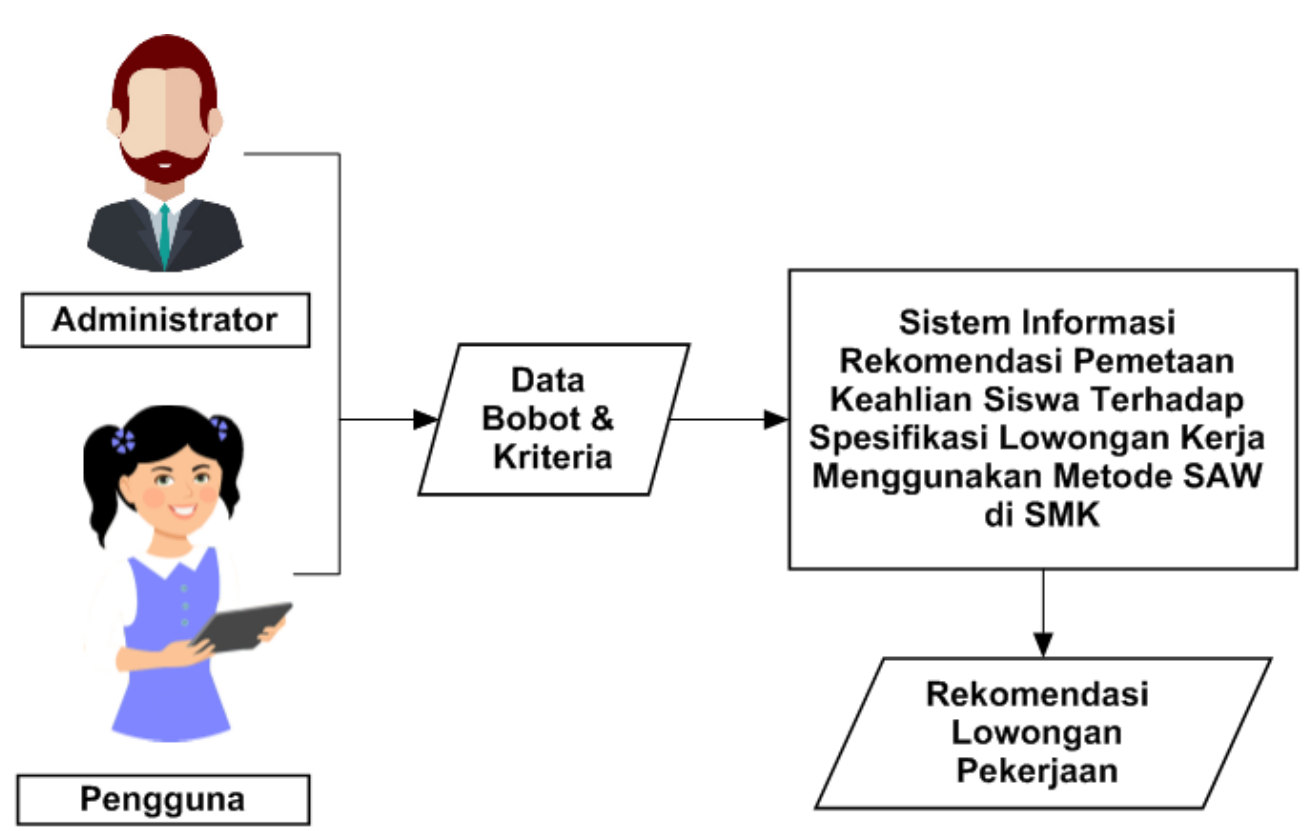

Gambar 2. Model Alur Sistem Informasi Rekomendasi

\section{Desain Model Sistem}

Model sistem informasi ini sama seperti alur pada Gambar 2. Dimulai dari admin memasukkan data-data lowongan perusahaan secara lengkap sesuai dengan kriteria yang dibutuhkan. Data lowongan ini yang nantinya menjadi alternatif dari rekomendasi pengguna.

Setelah terdapat data lowongan, pengguna kemudian memasukkan data diri sesuai permintaan sistem kemudian memasukkan kriteria sesuai yang dimiliki dan diinginkan. Pada langkah terakhir, pengguna diminta menentukan bobot setiap kriteria, baru setelah menentukan bobot, alternatif lowongan hasil rekomendasi akan muncul beserta preferensinya. Setiap langkah sangat penting karena akan menentukan munculnya rekomendasi alternatif lowongan kerja sesuai nilai preferensi.
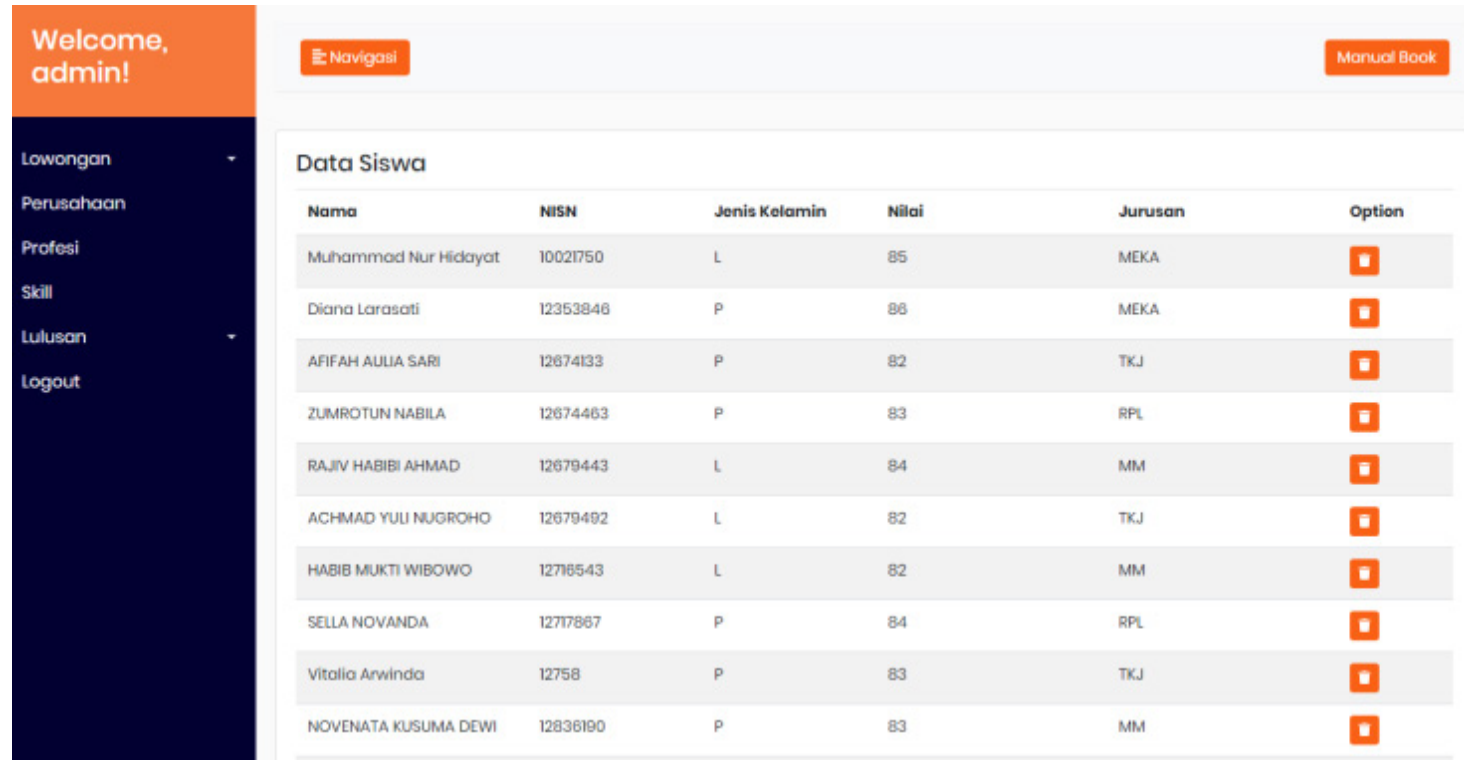

Gambar 3. Antarmuka Halaman Admin 


\section{Bobot Kriteria}

Bobot Nilai Rata

Nilai bobot nilai rata: 5

(semakin kekanan (nilai tertinggi). maka berarti semakin besar bobot yang anda berikan)

Bobot Gaji :

Nilai bobot gaji: 5

(semakin kekanan (nilai tertinggi), maka berarti semakin besar bobot yang anda berikan)

Bobot Jurusan

Nilai bobot jurusan : 5

(semakin kekanan (nilai tertinggi), maka berarti semakin besar bobot yang anda berikan)

Bobot Skill :

Nilai bobot skill : 5

(semakin kekanan (nilai tertinggi). maka berarti semakin besar bobot yang anda berikan)

Bobot Lokasi

Nilai bobot lokasi 5

(semakin kekanan (nilai tertinggi), maka berarti semakin besar bobot yang anda berikan)

Gambar 4. Antarmuka Pemberian Nilai Bobot Kriteria

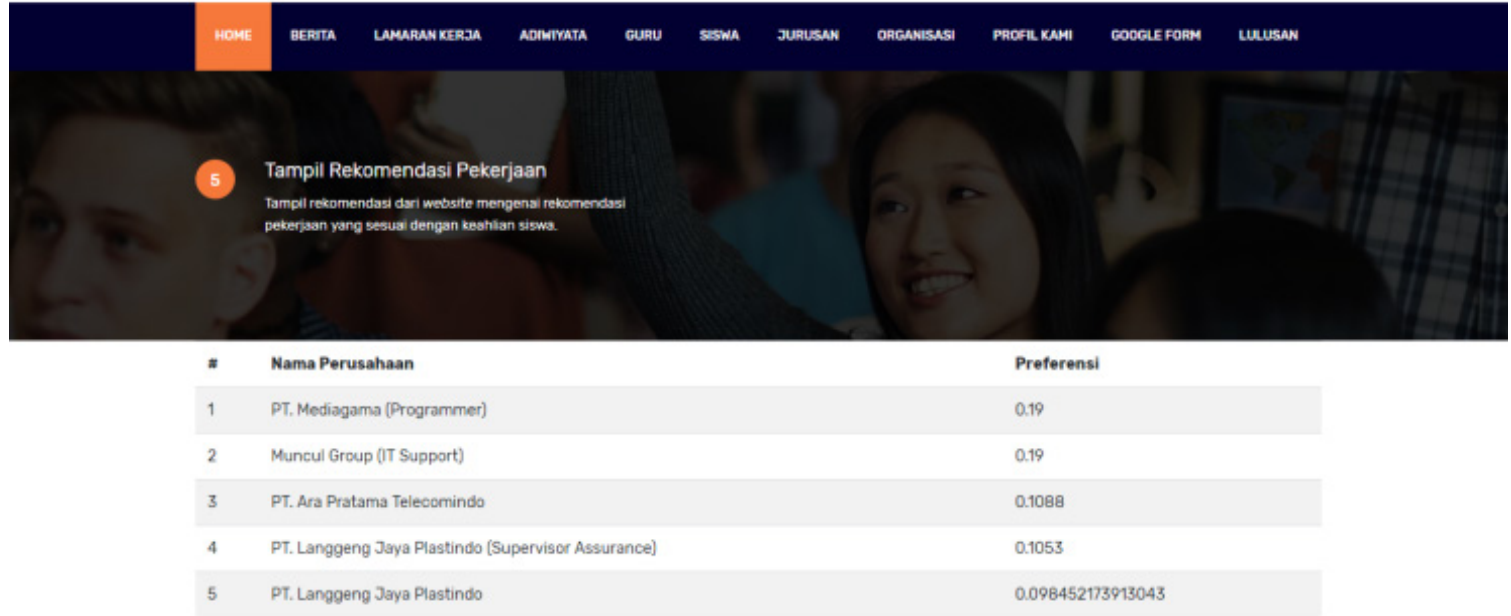

Gambar 5. Antarmuka Alternatif Lowongan Pekerjaan 
Penelitianinibertujuanuntukmengembangkan sistem informasi rekomendasi pemetaan keahlian siswa terhadap spesifikasi lowongan kerja dengan menggunakan metode SAW sebagai penentu rekomendasi. Sistem ini dilengkapi dengan buku panduan sebagai panduan dalam penggunaan sistem informasi.

\section{Validasi Ahli Sistem Informasi I dan Ahli Sistem Informasi II}

Validasi dilakukan untuk menguji fungsionalitas tingkat pengguna dan ahli sistem. Fungsionalitas yang dinilai sesuai dengan kebutuhan fungsionalitas sistem.

Tabel 14. Hasil Validasi Ahli Sistem I dan Ahli Sistem II

\begin{tabular}{|c|c|c|c|c|}
\hline No & Aspek Fungsionalitas & $x$ & $X i$ & $\mathrm{P}$ \\
\hline 1 & Autentifikasi & 4 & 4 & $100 \%$ \\
\hline 2 & Memasukkan data & 64 & 64 & $100 \%$ \\
\hline 3 & Mengubah data & 20 & 20 & $100 \%$ \\
\hline 4 & Menghapus data & 16 & 16 & $100 \%$ \\
\hline 5 & Pencarian data & 10 & 10 & $100 \%$ \\
\hline 6 & $\begin{array}{l}\text { Menampilkan hasil } \\
\text { rekomendasi }\end{array}$ & 2 & 2 & $100 \%$ \\
\hline 7 & Memasukkan database & 6 & 6 & $100 \%$ \\
\hline 8 & $\begin{array}{l}\text { Mengunduh buku } \\
\text { panduan }\end{array}$ & 4 & 4 & $100 \%$ \\
\hline \multicolumn{2}{|c|}{ Total skor } & 126 & 126 & \\
\hline \multicolumn{2}{|c|}{ Presentase kriteria } & & & $100 \%$ \\
\hline
\end{tabular}

Hasil validasi oleh ahli sistem informasi I dan $\mathrm{II}$, total jawaban benar responden $(\mathrm{x})$ adalah 126 begitu juga jawaban benar soal (xi) yaitu 126. Masing-masing dari ahli sistem informasi memperoleh nilai presentase $100 \%$.

\section{Uji Coba Pengguna}

Uji coba pengguna dilakukan kepada siswa SMKN 2 Singosari kelas XI jurusan TKJ, RPL, Mekatronika dan Multimedia. Jumlah sampel uji coba berjulah 158. Hasil instrumen uji coba disajikan dalam Tabel 15.

Tabel 15. Hasil Uji Coba Pengguna

\begin{tabular}{|c|l|l|l|l|}
\hline No & $\begin{array}{l}\text { Aspek } \\
\text { Fungsionalitas }\end{array}$ & X & Xi & P \\
\hline 1 & $\begin{array}{l}\text { Memasukkan } \\
\text { Data }\end{array}$ & 3403 & 3476 & $97,8 \%$ \\
\hline
\end{tabular}

\begin{tabular}{|c|l|l|l|l|}
\hline 2 & $\begin{array}{l}\text { Mengubah } \\
\text { Data }\end{array}$ & 615 & 632 & $97,3 \%$ \\
\hline 3 & $\begin{array}{l}\text { Menghapus } \\
\text { Data }\end{array}$ & 152 & 158 & $96,2 \%$ \\
\hline 4 & $\begin{array}{l}\text { Menampilkan } \\
\text { Hasil } \\
\text { Rekomendasi }\end{array}$ & 154 & 158 & $97,4 \%$ \\
\hline 5 & $\begin{array}{l}\text { Mengunduh } \\
\text { buku panduan }\end{array}$ & 151 & 158 & $95,5 \%$ \\
\hline Total Skor & 4477 & 4582 & \\
\hline \multicolumn{2}{|l}{ Presentase Kriteria } & & $97,47 \%$ \\
\hline
\end{tabular}

Hasil uji coba pengguna diperoleh hasil jawaban benar responden $(x)$ sejumlah 4477 dari total hasil jawaban benar soal (xi) 4582. Untuk mendapatkan presentase valid atau tidaknya sistem digunakan persamaan 5 untuk menghitung dan didapatkan presentase kelayakan sebesar $97,47 \%$.

\section{Pembahasan}

Berdasarkan hasil validasi oleh ahli sistem informasi I dan ahli sistem informasi II, diperoleh presentase fungsionalitas sebesar $100 \%$ yang menandakan semua aspek fungsionalitas bekerja dengan baik dan dinyatakan valid karena telah melampaui batas minimal dari valid yaitu $76 \%$.

Uji coba pengguna yang dilakukan pada siswa SMK memperoleh presentase fungsionalitas sebesar 97,47\%. Merujuk pada Tabel 13, sistem informasi yang dikembangkan dinyatakan valid. Presetase tidak dapat menunjukkan 100\% dikarenakan 2,53\% dari siswa SMK mendapati beberapa aspek fungsionalitas tidak berfungsi secara baik pada perangkat mereka.

\section{SIMPULAN}

Sistem informasi rekomendasi pemetaan keahlian siswa terhadap spesifikasi lowongan kerja menggunakan metode SAW di SMK dapat mempertemukan penyedia lowongan kerja dengan para pencari kerja melalui hasil rekomendasi dari sistem.

Penggunaan metode Simple Additive Weighting (SAW) dapat menghasilkan rekomendasipencarikerja terbaikberdasarkan kriteri yang dibutuhkan pengguna. 
Hasil uji coba dan validasi dari pengembangan sistem informasi yang telah dilakukan pada ahli sistem informasi dan pengguna, diketahui telah memenuhi kriteria sangat valid dan layak digunakan. Hal ini terbukti dari presentase keberhasilan fungsionalitas dari validasi ahlis sistem informasi yaitu $100 \%$ dan uji coba pengguna sebesar 97,47\%. Hasil tersebut telah menunjukkan bahwa sistem informasi sudah sangat valid karena melebihi batas minimal $76 \%$ untuk kriteria sangat valid.

\section{DAFTAR PUSTAKA}

Alshamrani, A., \& Bahattab, A. (2015). A Comparion Between Three SDLC Models Waterfall Model, Spiral Model, and Incremental/Iterative Model. International Journal of Computer Science Issues (IJCSI), 12(1).

Amalina, \& Putri, Y. D. (2017). Pengembangan Sistem Informasi Pengembangan Sistem Informasi Berbasis Web untuk Peningkatan Kinerja Unit Bursa Kerja Khusus SMK Negeri 1 Tanjung Raya. Jurnal IImiah IImu Komputer dan Informatika, 3(2), 7.

Arikunto, S. (t.t.). Prosedur Penelitian Suatu Pendekatan Praktik. Jakarta: Rineka Cipta.

Balaji, S. (2012). WATEERFALLVs V-MODEL Vs AGILE: A COMPARATIVE STUDY ON SDLC. International Journal of Information Technology and Business Management, 2(1), 5.

Darmastuti, D. (2013). Implementasi Metode Simple Additive Weighting (SAW) dalam Sistem Informasi Lowongan Kerja Berbasis Web untuk Rekomendasi Pencari Kerja Terbaik. Jurnal Sistem Dan Teknilogi Infromasi JustIN, 1(2).

Elmunsyah, H., \& Fahmi, A. (2018). Implementasi Algoritma Simple Additive Weighting untuk Menentukan Reviewer PKM pada Portal PKM di Universitas Negeri Malang (Skripsi). Jurusan Teknik Elektro-Fakultas Teknik UM, Malang.

Firdausa, F., Wibawa, A. P., \& Pujianto, U. (2016). Model Sistem Pendukung Keputusan Pemilihan Sekolah Menggunankan Metode SAW (Skripsi).
Jurusan Teknik Elektro-Fakultas Teknik UM, Malang.

Haryani, D., Sumadi, S., \& Supomo, K. (t.t.). Eksistensi, Peran, dan Fungsi Lembaga Bursa Kerja Khusus di Sekolah Menengah Kejuruan. Jurnal Manajemen Mutu Pendidikan, 1(3).

Jaya, T. S. (t.t.). Pengujian Aplikasi dengan Metode Blackbox Testing Boundary Value Analysis (Studi Kasus: Kantor Digital Politeknik Negeri Lampung). Jurnal Pengembangan IT, 3(1).

Mukodimah, S., Muslihudin, M., Andoyo, A., Hartati, S., \& Maseleno, A. (2018). Fuzzy Simple Additive Weighting and its Application to Toddler Healthy Food. International Journal of Pure and Applied Mathematics, 118(7), 8.

Mutaqin, A., Wibawa, A. P., \& Pujianto, U. (2016a). Model Analisis Pengambilan Keputusan Peminatan di SMA Menggunakan Metode SAW. Prosiding SAKTI (Seminar IImu Komputer dan Teknologi Informasi), 1(1), 123-126.

Noviarti, T., Muslihudin, M., Irviani, R., Maseleno, A., Fauzi, \& Nungsiyati. (2018). Optimal Dengue Endemic Region Prediction using Fuzzy Simple Additive Weighting based Algorithm. International Journal of Pure and Applied Mathematics, 118(7), 6.

Pambayun, N. A. Y., \& Wagiran, W. (2014). Kinerja bursa kerja khusus (BKK) SMK Negeri bidang keahlian teknologi dan rekayasa di Kabupaten Sleman. Jurnal Pendidikan Vokasi, 4(2). https://doi. org/10.21831/jpv.v4i2.2550

Pressman, R. S. (2015). Rekayasa Perangkat Lunak: Pendekatan Praktisi Buku I. Yogyakarta: Penerbit Andi.

Rahardjo, R. S. (2012). Kualitas Layanan Bursa Kerja Khusus dan Persepsi Alumni SMK Se Kabupaten Kendal Jawa Tengah. Jurnal Teknologi, Kejuruan dan Pengajarannya, 32(1).

Romadhoni, E. N. A., Widiyaningtyas, T., \& Pujianto, U. (2015). Implementasi Model Waterfall pada Pengembangan Sistem Informasi Alumni SMKN 1 Jenangan Ponorogo. Seminar Nasional Sistem Informasi Indonesia (SESINDO), 
2015.

Sahir, S. H., Rosmawati, R., \& Minan, K. (t.t.). Simple Additive Weighting Method to Determining Employee Salary Increase Rate. 7.

Santoso, P. A., Wibawa, A. P., \& Pujianto, U. (2018). Internship recommendation system using simple additive weighting. Bulletin of Social Informatics Theory and Application, 2(1), 15-21. https://doi. org/10.31763/businta.v2i1.102
Triswandi, N. A. (2015). Pengembangan Sistem Informasi Bursa Kerja Khusus Berbasis Web di SMK Islam Batu (Skripsi). Jurusan Teknik Elektro-Fakultas Teknik UM, Malang.

Zakaria, Elmunsyah, H., \& Fahmi, A. (2018). Implementasi Algoritma Simple Additive Weighting untuk Menentukan Reviewer PKM pada Portal PKM di Universitas Negeri Malang (Skripsi). Jurusan Teknik Elektro-Fakultas Teknik UM, Malang. 